\title{
Synthesis and Evaluation of Vanillin Derivatives as Antimicrobial Agents
}

\author{
Vanilin Türevlerinin Antimikrobiyal Ajanlar Olarak Sentezi ve \\ Değerlendirilmesi
}

\author{
(D) Rakesh YADAV*, (D) Dharamvir SAINI, (D) Divya YADAV \\ Banasthali University, Faculty of Pharmacy, Rajasthan, India
}

\begin{abstract}
Objectives: The present work involves the synthesis of novel acetyl vanillin derivatives and evaluation for their anti-microbial potential against Escherichia coli.

Materials and Methods: The titled compounds were prepared by reacting acetyl nitro vanillin with different substituted amines (Schiff base). The starting material acetyl nitro vanillin was synthesized by reacting acetyl vanillin with fuming nitric acid which in turn was prepared from 4-hydroxy3-methoxybenzaldehyde (vanillin).

Results: The chemical structures of the synthesized compounds were confirmed on the basis of their spectral data (FT-IR, UV/Visible, ${ }^{1} \mathrm{H}-\mathrm{NMR}$, Mass spectra).

Conclusion: All the synthesized compounds were tested in vitro for antimicrobial activity and compound F \& I showed significant activity as compared to the standard drug.
\end{abstract}

Key words: Vanillin, antimicrobial activity, Schiff bases, ciprofloxacin

öz

Amaç: Mevcut çalışma, yeni asetil vanilin türevlerinin sentezini ve Escherichia coli'ye karşı antimikrobiyal potansiyelinin değerlendirilmesini içerir. Gereç ve Yöntemler: Başlıktaki bileşikler, asetil nitro vanilinin farklı ikame edilmiş aminler (Schiff baz) ile reaksiyona sokulmasıyla hazırlandı. Başlangıç malzemesi asetil nitro vanilin, asetil vanilinin, sırasıyla 4-hidroksi-3-metoksibenzaldehitten (vanilin) hazırlanan dumanlı nitrik asit ile reaksiyona sokulmasıyla sentezlenmiştir.

Bulgular: Sentezlenen bileșiklerin kimyasal yapıları, spektral verilerine (FT-IR, UV/Görünür, ${ }^{1} \mathrm{H}-\mathrm{NMR}$, Kütle spektrumu) dayanarak teyit edildi.

Sonuç: Sentezlenen tüm bileșikler, antimikrobiyal aktivite için in vitro olarak test edildi ve bileșik F \& I, standart ilaçla karșılaștırıldığında önemli aktivite gösterdi.

Anahtar kelimeler: Vanilin, antimikrobiyal aktivite, Schiff bazları, siprofloksasin

\section{INTRODUCTION}

Antimicrobial agents like penicillins, cephalosporins, tetracyclines, nitrobenzene derivatives, macrolide antibiotics (erythromycin, roxithromycine etc.), polypeptide antibiotics (polymixin-B, Bacitracin etc.), nicotinic acid derivatives derived from the various sources are currently available in the market. But microbial resistance in most of the pathogenic bacteria to these drugs repeatedly appears. In order to check this consequential medical problem, the extension of newer varieties of antimicrobial agents is a prominent task. Vanillin (4-hydroxy- 3-methoxybenzaldehyde), a dietary flavoring agent, has been reported to show antioxidant and anti-mutagenic activities, and has also been proved to be an anti carcinogen against a variety of chemical and physical agents. ${ }^{2,3}$

Vanillin is considered to be one of the most widely appreciated flavoring compounds. In spite of its flavor qualities, vanillin exhibits the antimicrobial potential and has been used as a natural food preservative. ${ }^{4}$ Many natural compounds, including phenolic compounds derived from plants, exhibit strong antimicrobial properties and therefore have the potential to be applied to food 
products as novel preservatives. ${ }^{5}$ It is investigated that vanillin primarily affects the cytoplasmic membrane of the food-related bacteria Escherichia coli, Lactobacillus plantarum and Listeria innocua. The antimicrobial activity of vanillin and related derivatives was found to be dependent on the time of exposure, concentration and the target organism. The inhibitory action of vanillin is more effective against non-lactic Gram-positive than Gram-negative bacteria. ${ }^{6}$ The minimal inhibitory concentrations of vanillin is bacteriostatic in contrast to the more potent phenolic antimicrobials such as carvacrol and thymol, which are bactericidal. 7.8

The mode of action of nearly all antimicrobials can be classed into one or more of the following groups: (a) reaction with the cell membrane, (b) inactivation of essential enzymes, or (c) destruction or inactivation of genetic material." Phenolic compounds are hydrophobic in nature and are therefore regarded as membrane active. ${ }^{10}$

On the basis of these observations we tried our efforts to synthesize some nitro vanillin derivatives, starting with vanillin, which possess minimum microbial resistance and better activity. We know report the synthesis of these new compounds and resulting structure activity relationships for zone inhibition.

\section{EXPERIMENTAL}

All reagents and chemicals were used as obtained from the commercial supplier without further purification. All moisture sensitive reactions were carried out under dry nitrogen atmosphere. Column chromatography was carried out using silica gel 60-120 mesh size and distilled solvents. Thin layer chromatography (TLC) analyses were performed on precoated silica gel plates (GF254, Merck). Infrared (IR) spectra were recorded on BRUKER ALPHA using ATR technique. Proton nuclear magnetic resonance ('H-NMR) spectra were recorded on a BRUKER AVANCE I| $400 \mathrm{MHz}$ spectrometer in deuterated solvents. The chemical shifts are reported in $\delta(\mathrm{ppm})$ relative to internal standard tetramethylsilane and coupling constants $J$ are given in Hertz. Mass spectrometry was conducted using Agilent 1100 LC has been coupled with Bruker mass spectrometer model Esquire 3000.

\section{RESULTS}

The designed compounds on the basis of various literature reports were synthesized according to the following synthetic Scheme 1. The starting material vanillin was used to afford

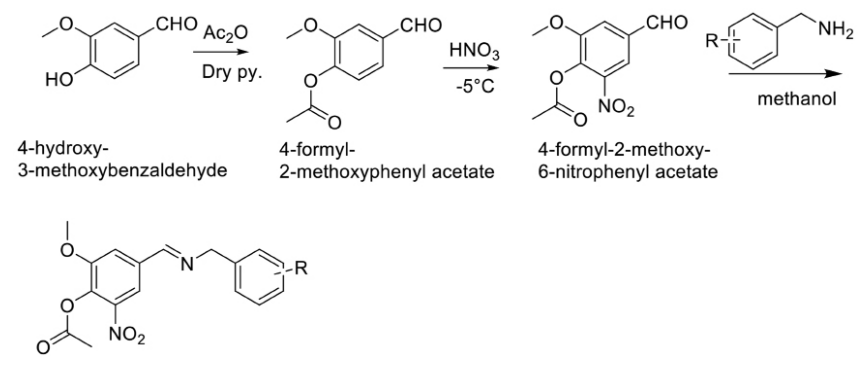

Scheme 1. the targeted compounds A-J, with as series of reaction. The completion of reaction was monitored with the help of TLC at each step. The compounds were characterized for physical parameters and tabulated in Table 1.

The chemical structures of the synthesized compounds were confirmed using various spectral techniques such as IR, NMR, Mass etc. are mentioned in the experimental part.

The acetylation of vanillin was confirmed with presence of carbonyl peak in IR at $\sim 1695 \mathrm{~cm}^{-1}$ and resonance of methyl protons at $\sim 2.29 \mathrm{ppm}$ in ${ }^{1} \mathrm{H}-\mathrm{NMR}$. Further nitration of compounds was confirmed by appearance of IR peak at $\sim 1540 \mathrm{~cm}^{-1}$ in various derivatives (A-J). Substitution of various amines was confirmed by the presence of IR peak at $\sim 1370 \mathrm{~cm}^{-1}$ whereas proton resonance at $\sim 8.5 \mathrm{ppm}$ in all the synthesized compounds. Although the compounds showed significant activity as compared to the standard but compounds $F$ (fluorine substituted) and I (pyridine substituted) showed similar inhibition $(25 \mu \mathrm{g} / \mathrm{mL}$ ) as compared to ciprofloxacin $(10 \mu \mathrm{g} / \mathrm{mL})$. This study revealed that there must be proper electron withdrawing substituents at para position of the substituted amines to have potent activity.

\section{Experimental work}

\section{General method for preparation of acetyl vanillin}

Vanillin $(3.2 \mathrm{mmol}$ ) was dissolved in dichloromethane (DCM) $(5-6 \mathrm{~mL})$ and acetic anhydride $(3.84 \mathrm{mmol})$ and dry pyridine (3.84 mmol) were added to this solution under anhydrous conditions. This mixture was stirred for 3-4 hrs at room temperature. Completion of reaction is detected by TLC in 1:1 Hexane: Ethyl acetate. The solvent DCM was evaporated and the mixture was poured on crushed ice. Precipitates obtained were filtered and rinsed with water, dried the precipitate and re-crystallized from $95 \%$ ethanol.

\section{General method for preparation of acetyl nitro vanillin}

Acetyl vanillin (2.59 mmol) was dissolved in $5 \mathrm{~mL}$ of DCM. This mixture was kept in -5 to $-10^{\circ} \mathrm{C}$ ice bath and stirred. When clear solution is obtained, $2 \mathrm{~mL}$ of fuming nitric acid was added to this reaction mixture then stirred for $1-2 \mathrm{hr}$ at room temperature. For work up add ice cold water was added, the precipitate was obtained, this obtained precipitate filtered washed and dryed. TLC taken in 1:1 Hexane: Ethyl acetate.

\section{General method for preparation of Schiff bases}

Equimolar mixture of acetyl nitro vanillin $(0.418 \mathrm{mmol})$ was dissolved in $25 \mathrm{~mL}$ of ethanol and then various amines (A-J) ( $0.428 \mathrm{mmol}$ ) were added to the mixture and stirred for 2-3 hrs at ambient temperature. The completion of reaction was detected by the TLC in 1:1 Hexane: Ethyl acetate. Solvent evaporated and oily compounds were collected.

2-Methoxy-4-(((2-methylbenzyl)-imino)-methyl)-6nitrophenyl acetate $(A)$

${ }^{1} \mathrm{H}-\mathrm{NMR}$ : $\delta 2.29$ (s, 3H, $\mathrm{CH}_{3}$ ), 2.38 (s, 3H, $\mathrm{CH}_{3}$ ), 3.83 (s, 3H, O- $\mathrm{CH}_{3}$ ), 4.87 (s, $2 \mathrm{H}, \mathrm{CH}_{2}-\mathrm{N}$ ), 7.16-7.10 (tt, J=5.2, 5.0, 5.0, 5.2 3H, $\mathrm{CH}_{2}-\mathrm{Ar}$ ), 7.34 (d, J=7.2, 1H, CH-Ar), 8.05 (s, 2H, CH-Ar) and 8.65 (s, $1 \mathrm{H}, \mathrm{CH}=\mathrm{N}-$ ) ppm. ESI-MS (m/z): 342. IR: 1467, 1643, 1695, 1019, 1538, 1371, 1597. 
Table 1. Physical constant of Schiff bases

S. No.

Code

$\mathrm{R}=$ Amine

M.F.

M. Wt. g/mol

M.P.

Yield

A<smiles>Cc1ccccc1CN</smiles>

$\mathrm{C}_{18} \mathrm{H}_{18} \mathrm{~N}_{2} \mathrm{O}_{5}$

342.35

Oily mass

$60 \%$

B<smiles>N#Cc1ccc(N)cc1C(F)(F)F</smiles>

$\mathrm{C}_{18} \mathrm{H}_{12} \mathrm{~F}_{3} \mathrm{~N}_{3} \mathrm{O}_{5}$

407.31

Oily mass

$40 \%$

C<smiles>NCc1ccccc1[N+](=O)[O-]</smiles>

$\mathrm{C}_{17} \mathrm{H}_{15} \mathrm{~N}_{3} \mathrm{O}_{7}$

Oily mass

$35 \%$

D<smiles>COc1cc(CN)ccc1O</smiles>

$\mathrm{C}_{19} \mathrm{H}_{20} \mathrm{~N}_{2} \mathrm{O}_{7}$

388.38

Oily mass

$52 \%$

I<smiles>Nc1ccc(F)cc1</smiles>

$\mathrm{C}_{16} \mathrm{H}_{13} \mathrm{FN}_{2} \mathrm{O}_{5}$

332.29

Oily mass

$47 \%$

5

E<smiles>NCc1ccc(F)cc1</smiles>

$C_{17} \mathrm{H}_{15} \mathrm{FN}_{2} \mathrm{O}_{5}$

346.31

Oily mass

$34 \%$

6

F<smiles>COc1ccc(N)cc1OC</smiles>

$\mathrm{C}_{18} \mathrm{H}_{18} \mathrm{~N}_{2} \mathrm{O}_{7}$

374.35

Oily mass

$58 \%$<smiles>COc1cc(N)cc(OC)c1OC</smiles>

$\mathrm{C}_{19} \mathrm{H}_{20} \mathrm{~N}_{2} \mathrm{O}_{8}$

404.38

Oily mass

$53 \%$

8

H<smiles>NCCc1ccccn1</smiles>

$\mathrm{C}_{17} \mathrm{H}_{17} \mathrm{~N}_{3} \mathrm{O}_{5}$

343.34

Oily mass

$37 \%$<smiles>Nc1ccc2c(c1)OCCO2</smiles>

$\mathrm{C}_{18} \mathrm{H}_{16} \mathrm{~N}_{2} \mathrm{O}_{7}$

372.33

Oily mass

$46 \%$ 
4-(((4-Cyano-3-(trifluoromethyl)-phenyl)-imino)-methyl)-2methoxy-6-nitro- phenyl acetate $(B)$

'H-NMR: $\delta 2.18$ (s, 3H, $\left.\mathrm{CH}_{3}\right), 3.73\left(\mathrm{~s}, 3 \mathrm{H}, \mathrm{O}-\mathrm{CH}_{3}\right), 6.27(\mathrm{~s}, 2 \mathrm{H}, \mathrm{CH}-$ $\mathrm{Ar}), 7.19$ (s, 1H, CH-Ar), 7.48 (s, 1H, CH-Ar), 8.08 (s, 1H, CH-Ar) and $8.11(\mathrm{~s}, 1 \mathrm{H}, \mathrm{CH}=\mathrm{N}-)$ ppm. ESI-MS (m/z): 407. IR: 2218, 1643, 1696, 1021, 1541, 1359, 1609, 1171.

\section{2-Methoxy-6-nitro-4-(((2-nitrobenzyl)-imino)-methyl)-phenyl} acetate (C)

'H-NMR: $\delta 2.23\left(\mathrm{~s}, 3 \mathrm{H}, \mathrm{CH}_{3}\right), 3.61\left(\mathrm{~s}, 3 \mathrm{H}, \mathrm{O}-\mathrm{CH}_{3}\right), 4.80(\mathrm{~s}, 2 \mathrm{H}$, $\mathrm{CH}_{2}-\mathrm{N}$ ), 7.16- 7.10 (tt, J=5.2, 5.0, 5.0, 5.2 3H, $\mathrm{CH}_{2}-\mathrm{Ar}$ ), 7.31 (d, $\mathrm{J}=7.2,1 \mathrm{H}, \mathrm{CH}-\mathrm{Ar}$ ), 8.15 (s, 2H, CH-Ar) and 8.23 (s, 1H, CH=N-) ppm. ESI-MS (m/z): 373. IR: 1467, 1592, 1651, 1025, 1524, 1343.

4-(((3,4-Dimethoxybenzyl)-imino)-methyl)-2-methoxy-6nitrophenyl acetate $(D)$

'H-NMR: $\delta 2.28$ (s, 3H, $\mathrm{CH}_{3}$ ), 3.83 (s, 9H, O- $\left.\mathrm{CH}_{3}\right), 4.87$ (s, $2 \mathrm{H}$, $\mathrm{CH}_{2}-\mathrm{N}$ ), 6.68 (d, J=7.2, 1H, CH-Ar), 6.76 (d, J=8.8, 1H, CH-Ar), 6.90 (s, 1H, CH-Ar), 8.05 (s, 2H, CH-Ar), 8.74 (s, 1H, CH=N-). ESI-MS (m/z): 388. IR: 1467, 1591, 1654, 1022, 1541, 1336.

4-(((4-Fluorophenyl)-imino)-methyl)-2-methoxy-6nitrophenyl acetate $(E)$

'H-NMR: $\delta 2.28$ (s, 3H, $\left.\mathrm{CH}_{3}\right), 3.83$ (s, 3H, O- $\left.\mathrm{CH}_{3}\right), 7.24$ (d, J=7.6, $2 \mathrm{H}, \mathrm{CH}_{2}-\mathrm{Ar}$ ), 7.32 (d, J=6.2, 2H, CH-Ar), 8.05 (s, 2H, CH-Ar), 8.66 (s, $1 \mathrm{H}, \mathrm{CH}=\mathrm{N}-$ ). ESI-MS (m/z): 332. IR: 1593, 1658, 1006 , 1545, 1384, 1609, 1154.

4-(((4-Fluorobenzyl)-imino)-methyl)-2-methoxy-6nitrophenyl acetate $(F)$

'H NMR: $\delta 2.28$ (s, 3H, $\mathrm{CH}_{3}$ ), 3.83 (s, 3H, O- $\mathrm{CH}_{3}$ ), 4.87 (s, $2 \mathrm{H}$, $\mathrm{CH}_{2}-\mathrm{N}$ ), 7.17 (d, J=7, 2H, $\mathrm{CH}_{2}-\mathrm{Ar}$ ), 7.22 (d, J=6,2H, CH-Ar), 8.05 (s, 2H, CH-Ar), 8.65 (s, 1H, CH=N). ESI-MS (m/z): 346. IR: 1507, 1652, 1090, 1062, 1546, 1385, 1438, 1120.

4-(((3,4-Dimethoxyphenyl)-imino)-methyl)-2-methoxy-6nitrophenyl acetate $(G)$

'H-NMR: $\delta 2.28$ (s, 3H, $\mathrm{CH}_{3}$ ), $3.83\left(\mathrm{~s}, 9 \mathrm{H}, \mathrm{O}-\mathrm{CH}_{3}\right), 6.78-6.76$ (d, $\mathrm{s}, \mathrm{J}=4.8,2 \mathrm{H}, \mathrm{CH}_{2}-\mathrm{Ar}$ ), 7.88 (d, J=10.0, 1H, CH-Ar), 8.05 (s, 2H, $\mathrm{CH}-\mathrm{Ar}$ ), 8.66 (s, 1H, CH=N). ESI-MS (m/z): 374. IR: 1467, 1655, 1593, 1024, 1545, 1384, 1609.

2-Methoxy-6-nitro-4-(((3,4,5-trimethoxyphenyl)-imino)methyl)-phenyl acetate $(H)$

'H-NMR: $\delta 2.28$ (s, 3H, $\mathrm{CH}_{3}$ ), $3.83\left(\mathrm{~s}, 12 \mathrm{H}, 0-\mathrm{CH}_{3}\right), 6.63(\mathrm{~s}, 2 \mathrm{H}$, $\mathrm{CH}-\mathrm{Ar}$ ), 8.05 (s, 2H, CH-Ar), $8.66(\mathrm{~s}, 1 \mathrm{H}, \mathrm{CH}=\mathrm{N}-$ ). ESI-MS (m/z): 404. IR: 1650, 1721, 1005, 1545, 1385, 1596.

2-Methoxy-6-nitro-4-(((2-(pyridin-2-yl)-ethyl)-imino)methyl)-phenyl acetate (I)

'H NMR: $\delta 2.29$ (s, $3 \mathrm{H}, \mathrm{CH}_{3}$ ), $3.26\left(\mathrm{t}, \mathrm{J}=7.0,2 \mathrm{H}, \mathrm{N}-\mathrm{CH}_{2} \mathrm{CH}_{2}\right), 3.83$ (s, 3H, O- $\mathrm{CH}_{3}$ ), $3.87\left(\mathrm{t}, \mathrm{J}=7.1,2 \mathrm{H}, \mathrm{CH}_{2}-\mathrm{N}\right), 7.25-7.20(\mathrm{~m}, \mathrm{~J}=4.7$, 8.0, 1.4, 4.7, 2H, CH-Ar), 7. 58 (t, J=4.5, 6.1, 1H, CH-Ar), 8.05 (s, $2 \mathrm{H}, \mathrm{CH}-\mathrm{Ar}$ ), 8.44 (d, J=9.8, 1H, CH-Ar), 8.65 (s, $1 \mathrm{H}, \mathrm{CH}=\mathrm{N})$. ESIMS (m/z): 343. IR: 1655, 1590, 1001, 1538, 1368, 1435.

4-(((2, 3-Dihydrobenzo-[b][1,4]-dioxin-6-yl)-imino)-methyl)2-methoxy-6-nitro-phenyl acetate $(\mathrm{J})$
'H NMR: $\delta 2.28$ (s, 3H, $\mathrm{CH}_{3}$ ), 3.83 (s, 3H, $\left.0-\mathrm{CH}_{3}\right), 4.28$ (s, $4 \mathrm{H}$, $\mathrm{CH}_{2}-0$ ), 6.78 (d, J=5.8, 2H, CH-Ar), 6. 89 (d, J=9.1, 1H, CH-Ar), 8.05 (s, 2H, CH-Ar), 8.66 (s, 1H, CH=N-). ESI-MS (m/z): 372. IR: 1656, 1597, 1017, 1535, 1426.

\section{Table 2. Antimicrobial activity of ciprofloxacin and synthesized}

compounds (A-J) on E. coli

\begin{tabular}{|c|c|c|}
\hline \multirow[b]{2}{*}{ S. No. } & \multirow{2}{*}{$\begin{array}{l}\text { Micro-organism } \rightarrow \\
\text { Sample } \downarrow\end{array}$} & E. coli \\
\hline & & $\begin{array}{l}\text { Zone of inhibition } \\
\text { Mean (mm) }\end{array}$ \\
\hline 1 & $\begin{array}{l}\text { Ciprofloxacin }(\mu \mathrm{g} / \mathrm{mL}) \\
30 \\
20 \\
10\end{array}$ & $\begin{array}{l}20 \pm 0.15 \\
18 \pm 0.13 \\
15 \pm 0.19\end{array}$ \\
\hline 2 & $\begin{array}{l}\text { Drug-A }(\mu g / m L) \\
100 \\
50 \\
25 \\
\end{array}$ & $\begin{array}{l}10 \pm 0.04 \\
8 \pm 0.11 \\
6 \pm 0.08\end{array}$ \\
\hline 3 & $\begin{array}{l}\text { Drug-B }(\mu g / m L) \\
100 \\
50 \\
25 \\
\end{array}$ & $\begin{array}{l}6 \pm 0.11 \\
6 \pm 0.16 \\
6 \pm 0.02 \\
\end{array}$ \\
\hline 4 & $\begin{array}{l}\text { Drug-C }(\mu g / m L) \\
100 \\
50 \\
25 \\
\end{array}$ & $\begin{array}{l}6 \pm 0.19 \\
6 \pm 0.11 \\
6 \pm 0.05 \\
\end{array}$ \\
\hline 5 & $\begin{array}{l}\text { Drug-D }(\mu g / m L) \\
100 \\
50 \\
25 \\
\end{array}$ & $\begin{array}{l}16 \pm 0.11 \\
10 \pm 0.03 \\
08 \pm 0.01 \\
\end{array}$ \\
\hline 6 & $\begin{array}{l}\text { Drug-E }(\mu g / m L) \\
100 \\
50 \\
25 \\
\end{array}$ & $\begin{array}{l}20 \pm 0.14 \\
15 \pm 0.13 \\
7 \pm 0.08 \\
\end{array}$ \\
\hline 7 & $\begin{array}{l}\text { Drug-F }(\mu \mathrm{g} / \mathrm{mL}) \\
100 \\
50 \\
25 \\
\end{array}$ & $\begin{array}{l}15 \pm 0.03 \\
13 \pm 0.13 \\
11 \pm 0.05 \\
\end{array}$ \\
\hline 8 & $\begin{array}{l}\text { Drug-G }(\mu \mathrm{g} / \mathrm{mL}) \\
100 \\
50 \\
25\end{array}$ & $\begin{array}{l}15 \pm 0.01 \\
8 \pm 0.17 \\
6 \pm 0.09\end{array}$ \\
\hline 9 & $\begin{array}{l}\text { Drug- } \mathrm{H}(\mu \mathrm{g} / \mathrm{mL}) \\
100 \\
50 \\
25\end{array}$ & $\begin{array}{l}10 \pm 0.06 \\
8 \pm 0.05 \\
6 \pm 0.10\end{array}$ \\
\hline 10 & $\begin{array}{l}\text { Drug-I }(\mu \mathrm{g} / \mathrm{mL}) \\
100 \\
50 \\
25\end{array}$ & $\begin{array}{l}15 \pm 0.11 \\
13 \pm 0.16 \\
10 \pm 0.02\end{array}$ \\
\hline 11 & $\begin{array}{l}\text { Drug-J }(\mu \mathrm{g} / \mathrm{mL}) \\
100 \\
50 \\
25\end{array}$ & $\begin{array}{l}14 \pm 0.04 \\
11 \pm 0.11 \\
6 \pm 0.08\end{array}$ \\
\hline
\end{tabular}




\section{Antimicrobial activity}

\section{Bacterial cultures}

Bacterial cultures were procured from microbial culture collection, National Centre for Cell Science, Pune, Maharashtra, India. The lyophilized cultures of bacterial strains upon culturing in nutrient broth for $24-48 \mathrm{hrs}$ at $37^{\circ} \mathrm{C}$ in an incubator resulted into turbid suspension of activated live bacterial cell ready to be used for microbiological study. The E. coli (Bact-1) used for antimicrobial studies was found to be active using well diffusion method $(100 \mu \mathrm{L})$. From the broth of respective revived cultures of bacteria, loop full of an inoculum was taken and streaked on to the nutrient agar medium and incubated again at same culture conditions and duration that yielded the pure culture colonies on to the surface of the agar culture that are successfully stored in refrigerated conditions at $4^{\circ} \mathrm{C}$ as stock culture to be used for further experimentation.

\section{Anti-biogram studies}

The antimicrobial activity of the synthesized compound against bacterial pathogens was used under present study. The synthesized compounds (A-J) were prepared in various concentrations (100, 50 and $25 \mu \mathrm{g} / \mathrm{mL}$ ) and applied on to the test organism using well diffusion method. Results of the experiment are being concluded in the Table 2, which clearly shows the anti-microbial activity of synthesized compound out of the bacterial strains used in the present work (Figure 1).

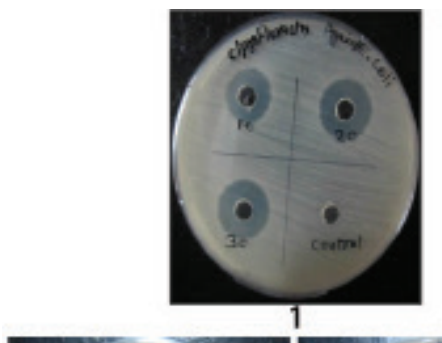

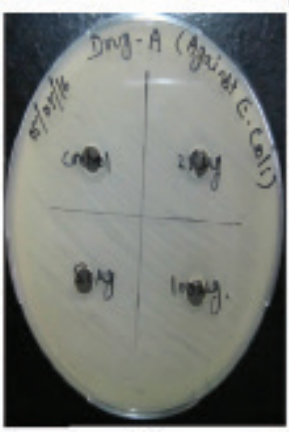

2

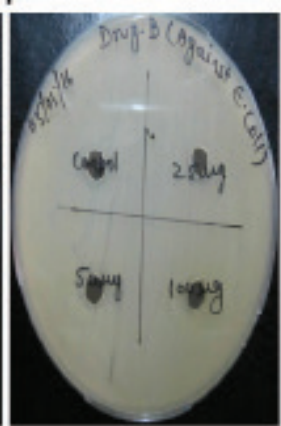

3

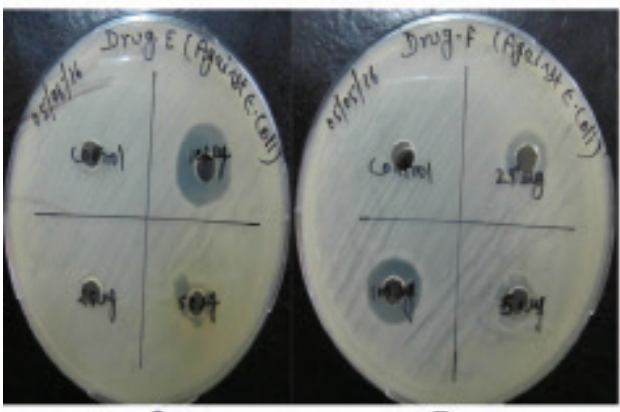

6

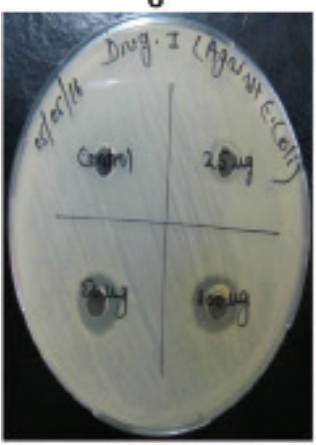

10

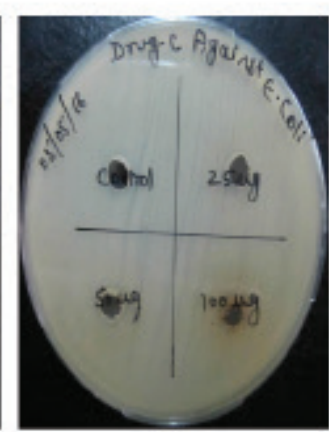

4

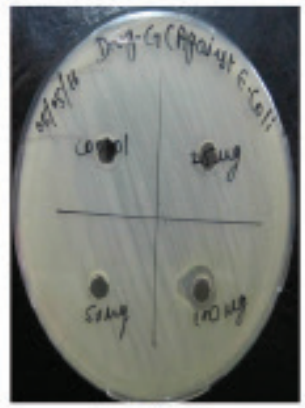

8

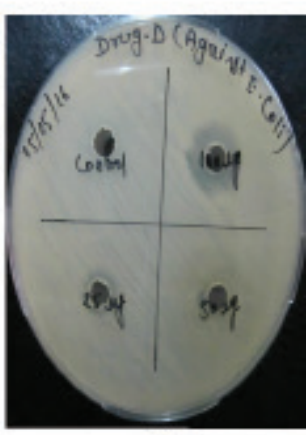

5

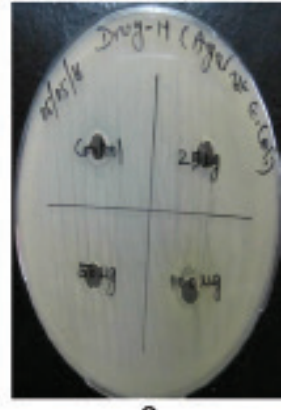

9

Figure 1. Antimicrobial activity of synthesized compounds (A-J) against E. coli 


\section{CONCLUSIONS}

We have reported a simple synthetic method of vanillin related derivatives. The reactions occurred very fast, in mild condition, using reasonable reagents and solvents with moderate yield. The antimicrobial activity of the synthesized compounds was effectively screened against $E$. coli. The compounds bearing electron withdrawing substituents $(F \& I)$ showed significant activity as compared to standard. The outcome of the work will be valuable for further studies in term of toxicity effect and quantity structure activity relationship to improve their biological and pharmacological properties.

\section{ACKNOWLEDGEMENTS}

Authors are thankful to the Vice-chancellor, Banasthali Vidyapith, Banasthali, India for providing constant support for research work. The financial assistance from DST-CURIE and MHRD, New Delhi is duly acknowledged.

Conflict of Interest: No conflict of interest was declared by the authors.

\section{REFERENCES}

1. Leeb M. Antibiotics: a shot in the arm. Nature. 2004;431:892-893

2. Hocking MB. Vanillin: synthetic flavoring from spent sulfite liquor. J Chem Educ. 1997;74:1055-1059

3. Evans JD, Martin SA. Effects of thymol on ruminal microorganisms. Curr Microbiol. 2000;41:336-340.

4. Kamat JP, Ghosh A. Devasagayam TP. Vanillin as an antioxidant in rat liver mitochondria: Inhibition of protein oxidation and lipid per oxidation induced by photosensitization. Mol Cell Biochem. 2000;209:47-53.

5. Beuchat LR, Golden DA. Antimicrobials occurring naturally in foods. Food Tech. 1989;43:134-142.

6. Jay JM, Rivers, GM. Antimicrobial activity of some food flavoring compounds. J Food Saf. 1984;6:129-139.

7. Ultee A, Gorris LG, Smid EJ. Bactericidal activity of carvacrol towards the food-borne pathogen Bacillus cereus. J Appl Microbiol. 1998;85:211-218.

8. Sikkema J, de Bont JA, Poolman B. Interactions of cyclic hydrocarbons with biological membranes. J Biol Chem. 1994;269:8022-8028.

9. Sikkema J, de Bont JA, Poolman B. Mechanisms of membrane toxicity of hydrocarbons. Microbiol Rev. 1995;59:201-222.

10. Cox SD, Mann CM, Markham JL, Bell HC, Gustafson JE, Warmington JR, Wyllie SG. The mode of antimicrobial action of the essential oil of Melaleuca alternifolia (tea tree oil). J Appl Microbiol. 2000;88:170-175. 